\title{
Factors Affecting Birth Weight in Sirohi Goat Kids
}

\author{
Ganesh Ram Jat*, Mahesh Datt, Vinod Bhateshwar and Shankar Lal Fogya \\ Department of Livestock Production Management \\ S K N College of Agriculture, Jobner(Jaipur) - 303329, India \\ *Corresponding author
}

\section{A B S T R A C T}

\section{Keyw ords \\ Birth weight, Goat, Kids, Season, Sex, Winter, Autumn \\ Article Info \\ Accepted: \\ 20 April 2018 \\ Available Online: \\ 10 May 2018}

\begin{abstract}
A study was conducted on birth weight Forty Sirohi goat kids (20 male and 20 female) were used to investigate the effect of sex, type of birth and season of birth weight. Season of kidding was classified as autumn and winter. The overall birth weight of kids was $2.57 \pm$ $0.036 \mathrm{~kg}$. The male kids showed significantly higher birth weight than female ie., $2.67 \pm 0.051$ and $2.46 \pm 0.041 \mathrm{~kg}$, respectively. This may be due to the effect of male sex hormone, which influences grow faster during pre-natal development. The kids born as single $(2.66 \pm 0.051 \mathrm{~kg})$ were significantly heavier than those born as twins $(2.30 \pm 0.052 \mathrm{~kg})$ which is obvious because in multiple births the nutrients available from the mother are shared by twin kids. Kids born during winter $(2.60 \pm 0.052 \mathrm{~kg})$ were heavier than kids born in the autumn season $(2.53 \pm 0.051 \mathrm{~kg})$. This might be due to better availability of good quality green fodder during breeding season and pregnancy period.
\end{abstract}

\section{Introduction}

The goat "Movable Wealth" for nomads, small and marginal farmers and land less labours has tremendous potential to be projected as the 'Animal of Future' for rural prosperity. The agro-geo-climatic conditions are changing and resources depleting continuously for crop-based livelihood. In India, we have 23 well defined goat breeds. India possesses the second-largest goat population in the world having 135.17 million goats, but their population has declined by $3.82 \%$ over the previous census (Anonymous, 2012). Goat farming plays an important role in the up liftment of rural economy and livelihood which is creates employment of rural youth. This is because goats can thrive in hardy weather conditions and can be conveniently reared on uncultivable land where dairy farming is not economical. Sirohi is a dual purpose breed of goat native of central and southern regions of Rajasthan. These goats breed have a high resistance to disease and adapt well to hot, dry deserts areas. Birth weight is an economic indicator for any livestock production purpose. There is a positive correlation in birth weight and further increasing of the live weight of animals (Roy et al., 1989). Studies of various authors show that birth weight is influenced by sex, type of birth, season of birth, maternal age and more (Supakorn and Pralomkarn, 2009; Bharathidhasan et al., 2009). The 
present study pertains to the effect of season of birth, sex of kid and type of birth in Sirohi goat kids as reported under intensive system. A flock of Sirohi goat kids (20 male and 20 female) goats were being maintained at, SKN College of Agriculture Jobner (Jaipur). Season of kidding was classified as autumn and winter. Hence, an attempt has been made to appreciate the pattern of seasonal births and their effect on birth weight in Sirohi goats under intensive system of management reared in an organized farm.

\section{Materials and Methods}

The birth record of 40 Sirohi goat kids (20 males and 20 females). Out of 40 goat kids, 30 kids were single born and remaining 10 kids were twins. The experiment was conducted at RKVY Project Sirohi goat farm, S.K.N. College of Agriculture, Jobner, District Jaipur, (Rajasthan, India). Geographically, Jobner is located $45.0 \mathrm{~km}$ west of Jaipur at $260 \mathrm{05}^{\prime}$ North latitude, 750 28' East longitude and at an altitude of 427 meter above sea level. There were two kidding seasons during the period of study i.e. autumn (October) and winter (December) in year 2015. The births recorded were also classified according to their sexes. Birth weights of 40 kids were classified according to sexes, type of birth (single/twins) and season. Fresh water was provided for $24 \mathrm{hrs}$ in the shed. The feeding practice remained uniform throughout the study period. The kids were provided with proper housing and were cared by staff and veterinary care provided as and when necessary. All kids were reared under intensive system of standard management practices. The animals were provided with anti-helminthetic preparations as per approved schedule and guidelines. During the experimental period all the weather protections were uniform. Data were analyzed according to the procedures suggested by Snedecor and Cochran (1994) and the difference between treatment means was tested for significance by Duncan's multiple range and $\mathrm{F}$ Test (Duncan, 1955).

\section{Results and Discussion}

\section{Effect of sex of kid on birth weight}

The data were tabulated according to the sex of kids to determine the effect of sex on birth weight. It was observed that out of total births of 40 , males were 20 and females 20 in ratio of 50 and 50 percent respectively. Table 1 shows that overall mean birth weight was $2.57 \pm 0.036 \mathrm{~kg}$. The result pertaining to the average body weight at birth for male kids and female kids were $2.67 \pm 0.051$ and $2.46 \pm 0.415$ $\mathrm{kg}$ respectively. It was also found that male kids weighed $8.54 \%$ higher birth weight than female kids in Sirohi goat kids. The statistical analysis of data revealed that sex had significant $(\mathrm{P}<0.01)$ effect on birth weight of Sirohi goat kids. Banerjee and Jana (2010) also reported significant effect of sex on birth weights in Sirohi goat kids. Present findings corroborated to reports of Chawla et al., (1984), Sanchez et al., (1994), Tomar et al., (1997), Raza et al., (1998), Elabid (2008), Bharthidhasan et al., (2009), Bhusan (2012), Singh et al., (2013) and Harikrishna et al., (2013). This may be due to anabolic effect of male hormones (Hafez, 1962 and Chandra et al., 2009) which influences growth factor during pre-natal development. However, Baiden (2007) reported similar birth weights $(P>0.05)$ between single births $(1.43 \pm 0.04 \mathrm{~kg})$ and twins $(1.34 \pm 0.03 \mathrm{~kg})$ but singles were significantly heavier $(P<0.05)$ than triplets $(1.24 \pm 0.05 \mathrm{~kg})$. This might be attributed to effect of location, breed and seasons in Ghana.

\section{Effect of season of birth weight}

The birth weight of a total 40 kids, 20 in autumn (October) and 20 in winter (December) was recorded during the 
experiment period. Table 1 revealed that the average birth weight of Sirohi goat kids was $2.53 \pm 0.051 \mathrm{~kg}$ and $2.60 \pm 0.052 \mathrm{~kg}$ during autumn and winter season respectively. It is clear from the table that the average birth weight of kids was higher during winter season than autumn season. This might be attributed to abundant availability of good quality green fodder during gestation period of does. In the present study, season had no significant effect on birth weight of Sirohi goat kids. Present findings were conformed to the work of Raza et al., (1998), Baiden (2007), Thiruvenkadan et al., (2008), Bharthidhasan et al., (2009), Chandra et al., (2009), and Bhusan (2012). However, Salah et al., (1989), Paul et al., (1990), Elabid (2008), Benerjee and Jana (2010), Meel et al., (2010) also reported significant effect of season on birth weight of goat kids. This might be attributed to effect of large number of observations, period, breed and environmental factors.

\section{Effect of birth type on birth weight}

Table 1 revealed that the mean birth weight of single birth of 30 kids and twin birth of 10 kids was $2.66 \pm 0.031 \mathrm{~kg}$ and $2.30 \pm 0.052 \mathrm{~kg}$, respectively. The statistical analysis of data showed that type of birth had significant $(\mathrm{P}<0.01)$ effect on birth weight of Sirohi goat kids. Banerjee and Jana (2010) also reported significant effect of type of birth on birth weights in Sirohi goat kids. The kids born as singles were heavier than those born as twins. Present findings is agreement to the reports of Tomar et al., (1997), Neeru and Kumar (2002), Thiruvenkadan et al., (2009), Elabid (2008), Bharthidhasan et al., (2009), Chandra et al., (2009), Bhusan (2012), Hristova et al., (2013) and Hegan et al., (2014). Higher birth weight of single born kids was due to more nutrition available from the mother during prenatal period. Another factor might be the limitation of space in the uterus for the growth of multiple kids during prenatal period. However, Baiden (2007) reported similar birth weights $(P>0.05)$ between single births $(1.43 \pm 0.04 \mathrm{~kg})$ and twins $(1.34 \pm 0.03 \mathrm{~kg})$ but singles were significantly heavier $(P<0.05)$ than triplets $(1.24 \pm 0.05 \mathrm{~kg})$ goat kids. This might be attributed to effect of location, periods, breed and seasons in Ghana.

Table.1 Birth weight in Sirohi goat kids for various parameters

\begin{tabular}{|c|c|c|c|}
\hline parameters & $\mathbf{N}$ & $\begin{array}{l}\text { Birth weight (Kg) } \\
\text { Mean } \pm \text { SE }\end{array}$ & Signficance \\
\hline Overall & 40 & $2.57 \pm 0.036$ & \\
\hline $\begin{array}{l}\text { Sex } \\
\text { Male } \\
\text { Female }\end{array}$ & $\begin{array}{l}20 \\
20\end{array}$ & $\begin{array}{l}2.67 \pm 0.051 \\
2.46 \pm 0.041\end{array}$ & $* *$ \\
\hline $\begin{array}{l}\text { Season } \\
\text { Autumn } \\
\text { Winter }\end{array}$ & $\begin{array}{l}20 \\
20\end{array}$ & $\begin{array}{l}2.53 \pm 0.051 \\
2.60 \pm 0.052\end{array}$ & NS \\
\hline $\begin{array}{l}\text { Type of birth } \\
\text { Single } \\
\text { Twins }\end{array}$ & $\begin{array}{l}30 \\
10\end{array}$ & $\begin{array}{l}2.66 \pm 0.031 \\
2.30 \pm 0.052\end{array}$ & $* *$ \\
\hline
\end{tabular}


In Sirohi goat, male kids were weighed $8.53 \%$ higher birth weight than that of female kids during the year of the experiment. Average birth weights of the kids were $2.53 \pm 0.051$ and $2.60 \pm 0.052 \mathrm{Kg}$ during autumn (October) and winter (December) season respectively. Birth weight in winter season was found higher than the autumn season but no significant effect of season was observed. It was found that on average birth weight of single born kids $(2.66 \pm 0.051 \mathrm{~kg})$ had significantly $(\mathrm{P}<0.01)$ higher birth weight than twins $(2.30 \pm 0.052 \mathrm{~kg})$ which was obvious because in multiple births the nutrients available from the mother are shared by twin kids. Another factor might be the limitation of space in the uterus for the growth of multiple kids during prenatal life.

\section{Acknowledgement}

We thankful to the assistance and encouragement received from our respective departments for providing the opportunity and facilities for carrying out the work.

\section{References}

Baiden, Y.S. 2007. Birth weight birth type pre-weaning survivability of West African dwarf goat raised in the Dangme West District of the Greater Accra region of Ghana. Tropical Animal Health and Production. 39: 141-147.

Banerjee, S. and Jana, D. 2010. Factors affecting birth weight of Sirohi goat kids reared in hot and humid climate of West Bengal. World Applied Sciences Journal. 9(12): 379-1382.

Bharathidhasan A, Rita Narayanan, Gopu P, Subramanian A, Prabakaran R and Rajendran R. 2009. Effect of nongenetic factors on birth weight, weaning weight and preweaning gain of Barbari goat. Tamilnadu J. Vet. \&
Anim. Sci. 5 (3): 99-103.

Bharathidhasan, A., R. Narayanan, P. Gopu, A. Subramanian, R. Prabakaran and R.

Bhusan, S. 2012. Effect of non- genetic factors on body weights of Jakhrana kids. Indian Journal of Small Ruminants. 18(2): 253-255.

Chandra, R., Karmkar, H.D., De, D., Kumar, S. and Rahman, H. 2009. Factor influencing birth weight of Sikkim local kids. Indian Journal of Small Ruminants. 15(1): 113-114.

Chawla, D.S., Nagpal, S. and Bhatnagar, D. S. 1984. Variation in body-weight gain of Beetal, Alpine and Saanen goats. Indian Journal of Animal Sciences. 54(7): 711 -714.

Duncan DB. 1955. Multiple range and multiple F tests. Biometrics 11: 1-42.

Elabid, E.H. 2008. Various factors affecting birth weight of Sudanese Nubian goat kids. Research Journal of Agriculture and Biological Sciences. 4(6): 700703.

growth in Jamnapari kids. Indian J. Anim. Sci. 59: 874-877.

Growth Traits in Goats for Meat Raised at a Commercial Farm in Southern Thailand. Thai

Hafez E.J.H. (1962). Reproduction in Farm Animals. 5th edition., Lea and Febiger, Philadelphia, USA pp: 410412.

Harikrishna, Ch., Raghunandan, T. and Gnana Prakash, M. 2013. Effect of season on kidding and birth weight in Osmanabadi goats reared in an organized farm, International Journal of Livestock Research. 3(2): 84-88.

Hegan, B.A., Nyameasem, J.K., AsafuAdjaye, A. and Duncan, J.L. 2014. Effects of non-genetic factors on the birth weight, litter size and preweaning survivability of West African Dwarf goats in the Accra Plains. Livestock Research for Rural 
Development. 26(1).138-142.

Hristova, T., Stoycheva, S., Zunev, P., Maslev, T. and Kovasevik, T. 2013. Non-genetic factors affecting birth weight of goat kids. Book of Proceedings. 12(2): 1066-1069.

J. Agricultural Sci. 42(1): 21-25.

Meel, U.K., Nagda, R.K., Sharma S.K. and Rajawat, B.S. 2010. Growth performance of Sirohi goats under field conditions. Indian Journal of Small Ruminants. 16(2): 246-248.

Neeru, D.S. and Kumar P. 2002. Factor affecting birth weight of kids in Indian goats. International Journal of Animal Sciences. 17: 57-60.

Paul, S., Sahu, B.B., Singh, D. and Rawat, P.S. 1990. Effect of season of birth, weaning age and concentrate supplementation on growth and chevon production. Indian Journal of Animal Production and Management. 6(4): 182-186.

Rajendran. 2009. Effect of non-genetic factors on birth weight, weaning weight and preweaning gain of Barbari goat, TamilNadu J. Vet. Anim. Sci. 5, 99103.

Raza, S.H., Tahir, M., Zia, S. Iqbal, A. and Shaqif, A. 1998. Impact of environmental factors on birth weight in Teddy goat. Asian Journal of Applied Sciences. 11(2): 152-154.

Raza, S.H., Tahir, M., Zia, S. Iqbal, A. and Shaqif, A. 1998. Impact of environmental factors on birth weight in Teddy goat. Asian Journal of Applied Sciences. 11(2): 152-154.

Roy, R., Prakash, B. and Khan, B.U. 1989. Genetic and non genetic sources of variation for

Salah, M.S., Bakkar M.N and Mogawer, H.H. 1989. Body weight of Aradi goat kids in Saudi Arabia at different ages and affecting factors. Journal of King Saud University. 1(1,2): 17-24.

Sanchez, G.F.F. Montaldo, V.H. and Hdrez, L.A. 1994. Environmental and genetic effects on birth weight in graded-up goat kids. Canadian Journal of Animal Science. 74: 397-400.

Singh, P., Singh, M.K. and Singh, S.K. 2013. Effect of non-genetic factors on body weights of Jamunapari goats. Effect of non-genetic factors on body weights of Jamunapari goats. Indian Journal of Jammu. 19(2): 146-150.

Supakorn, C. and W. Pralomkarn. 2009. Estimation of Genetic Parameters on Pre-Weaning

Thiruvenkadan, A.K., Chinnamani, K., Muralidharan, J. and Karunanithi, K. 2009. Factors affecting birth weight of Tellicherry kids. Indian Journal of Small Ruminants. 14(2): 255-258.

Tomar, A.K.S., Kumar, A. and Singh, N.P. 1997. Pattern of birth weight inheritance in Sirohi and Kutchi goat breed in semi-arid condition of western India. Indian Journal of Small Ruminants. 3(1): 1-4.

\section{How to cite this article:}

Ganesh Ram Jat, Mahesh Datt, Vinod Bhateshwar and Shankar Lal Fogya 2018. Factors Affecting Birth Weight in Sirohi Goat Kids. Int.J.Curr.Microbiol.App.Sci. 7(05): 2627-2631. doi: https://doi.org/10.20546/ijcmas.2018.705.304 